\title{
Strain-specific proteome responses of Pseudomonas aeruginosa to biofilm-associated growth and to calcium
}

\begin{abstract}
Correspondence
Michael J. Franklin

umbfm@montana.edu
\end{abstract}

Received 4 June 2007

Revised 23 July 2007

Accepted 26 July 2007

\author{
Marianna A. Patrauchan, ${ }^{1}$ Svetlana A. Sarkisova ${ }^{2}$ \\ and Michael J. Franklin 2,3 \\ ${ }^{1}$ Department of Microbiology and Immunology, University of British Columbia, Vancouver,
BC V6T 1Z3, Canada
${ }^{2}$ Department of Microbiology, Montana State University, Bozeman, MT 59717, USA
${ }^{3}$ Center for Biofilm Engineering, Montana State University, Bozeman, MT 59717, USA
}

Pseudomonas aeruginosa is an opportunistic pathogen that forms biofilms on mucous plugs in the lungs of cystic fibrosis (CF) patients, resulting in chronic infections. Pulmonary $P$. aeruginosa isolates often display a mucoid (alginate-producing) phenotype, whereas non-mucoid strains are generally associated with acute infections. We characterized the cytosolic proteomes of biofilm-associated and planktonic forms of a CF pulmonary isolate, $P$. aeruginosa FRD1, and a non-mucoid strain, PAO1. Since $\mathrm{Ca}^{2+}$ metabolism is altered in CF pulmonary fluids, we also analysed the effect of $\mathrm{Ca}^{2+}$ on the proteome responses of these strains. Both strains altered the abundances of $40-60 \%$ of their proteins in response to biofilm growth and/or $\left[\mathrm{Ca}^{2+}\right]$. Differentially expressed proteins clustered into 12 groups, based on their abundance profiles. From these clusters, 146 proteins were identified by using MALDI-TOF/TOF mass spectrometry. Similarities as well as strain-specific differences were observed. Both strains altered the production of proteins involved in iron acquisition, pyocyanin biosynthesis, quinolone signalling and nitrogen metabolism, proteases, and proteins involved in oxidative and general stress responses. Individual proteins from these classes were highly represented in the biofilm proteomes of both strains. Strain-specific differences concerned the proteins within these functional groups, particularly for enzymes involved in iron acquisition and polysaccharide metabolism, and proteases. The results demonstrate that a mucoid CF isolate of $P$. aeruginosa responds to biofilm-associated growth and $\left[\mathrm{Ca}^{2+}\right]$ in a fashion similar to strain PAO1, but that strain-specific differences may allow this CF isolate to successfully colonize the pulmonary environment.

\section{INTRODUCTION}

Pseudomonas aeruginosa is an opportunistic pathogen that can cause a variety of biofilm-associated diseases, including infections in burn wounds and tissue injuries (Costerton et al., 1995, 1999). P. aeruginosa is also one of the main organisms associated with pulmonary infections in patients undergoing immunosuppressive therapy, or patients with the genetic disorder cystic fibrosis (CF) (Lyczak et al., 2000). The ability of $P$. aeruginosa to cause disease is due to multiple factors including its inherent resistance to many antibiotics and its ability to produce a large repertoire of secreted virulence factors, such as exotoxins, proteases, lipases and pyocyanin (Stover et al., 2000). P. aeruginosa

Abbreviations: BMM, biofilm minimal medium; CF, cystic fibrosis; NV, normalized volume; PQS, Pseudomonas quinolone signal; 2DGE, twodimensional gel electrophoresis. also produces protective extracellular polysaccharides including alginate, $\mathrm{Psl}$ and $\mathrm{Pel}$ polysaccharides that contribute to biofilm formation (Friedman \& Kolter, 2004; Hentzer et al., 2001; Jackson et al., 2004; Nivens et al., 2001) and provide protection of the bacteria from host defensive responses (Lyczak et al., 2002; Mai et al., 1993; Pier et al., 2001).

Biofilm-associated infections are particularly important, since the bacteria growing in biofilms are often highly resistant to antibiotics and to host innate defensive processes (Jesaitis et al., 2003; Stewart \& Costerton, 2001). It is not entirely clear why the bacteria in biofilms have these enhanced resistances. In the case of antibiotics, studies have demonstrated that most antibiotics are not diffusion limited, and therefore adequately penetrate biofilms (Rani et al., 2005; Roberts \& Stewart, 2004; Walters et al., 2003). This suggests that bacterial physiology 
may dictate antibiotic resistance in biofilms, mechanisms of which have been proposed. For example, biofilmassociated $P$. aeruginosa may produce cyclic glucans, not produced by planktonic cells, to increase resistance (Mah et al., 2003). A subset of physiologically distinct bacteria with enhanced antibiotic resistance may repopulate biofilms following antibiotic treatment of the sensitive cells (Keren et al., 2004; Lewis, 2007). Cells with differing physiological properties within biofilms have been described, even for originally clonal cultures (Boles et al., 2004), suggesting that differences in antibiotic resistance may occur at the individual cell level. Although less well characterized, physiological properties of biofilm-associated bacteria may also influence the enhanced resistance of these bacteria to host defences (Jensen et al., 2007; Jesaitis et al., 2003). Since biofilm-associated P. aeruginosa appear to be physiologically different from cells in planktonic culture, several previous studies have used transcriptomic and proteomic approaches to identify changes in gene expression during $P$. aeruginosa biofilm development (Sauer et al., 2002; Southey-Pillig et al., 2005; Waite et al., 2005, 2006; Whiteley et al., 2001). Sauer et al. (2002) found that as much as $50 \%$ of the $P$. aeruginosa $\mathrm{PAO} 1$ proteome may differ during certain stages of biofilm development compared to planktonic cells. Some of these differences are likely to be responsible for the increased resistance of the bacteria to antibiotics and host defences.

Patients with CF are particularly susceptible to biofilm infections with $P$. aeruginosa due to mutations of the cystic fibrosis transmembrane regulator (CFTR), which lead to a build up of mucous in the pulmonary fluid (Lyczak et al., 2000). Calcium metabolism disorder is central to the pathology of CF (von Ruecker et al., 1984). Pulmonary fluid and nasal secretions in patients with CF contain elevated concentrations of $\mathrm{Ca}^{2+}$ (Halmerbauer et al., 2000; Lorin et al., 1976). Both $\mathrm{Ca}^{2+}$ influx and efflux increase in isolated CF mitochondria, resulting in net $\mathrm{Ca}^{2+}$ accumulation. Retention of CFTR in the endoplasmic reticulum is dependent upon chaperone proteins that require $\mathrm{Ca}^{2+}$ for optimal activity (Egan et al., 2002). $\mathrm{Ca}^{2+}$ also influences migration of eosinophils across lung epithelium (Liu et al., 1999). High levels of $\mathrm{Ca}^{2+}, \mathrm{Na}^{+}$and $\mathrm{Cl}^{-}$may influence release of cytotoxic eosinophil products, affecting mucociliary clearance and promoting epithelial-cell injury and fibrosis (Halmerbauer et al., 2000).

We have recently described the extracellular constituents of two $P$. aeruginosa strains growing in biofilms and exposed to elevated $\left[\mathrm{Ca}^{2+}\right]$ (Sarkisova et al., 2005). Several findings were surprising. First, elevated $\left[\mathrm{Ca}^{2+}\right]$ influenced biofilm architecture of both the alginate-producing $\mathrm{CF}$ isolate FRD1 and the non-mucoid strain PAO1. The effect was more dramatic for FRD1, with biofilms as much as 10-fold thicker when $\mathrm{Ca}^{2+}$ ions were added. This increased thickness was due primarily to increased biosynthesis of alginate, which was as much as eightfold induced in biofilms exposed to medium with $\mathrm{Ca}^{2+}$. The PAO1 biofilm architecture was also influenced by $\mathrm{Ca}^{2+}$, although to a lesser extent, and without production of alginate. Second, calcium influenced the production of extracellular proteases (alkaline protease, elastase and PrpL protease), which accumulated in the biofilm alginate matrix of the mucoid strain FRD1. Previously, it was thought that there was an inverse relationship between alginate production and production of extracellular proteins. Although this is the case for certain environmental conditions, when $\mathrm{Ca}^{2+}$ is present, both alginate and proteases are highly upregulated in biofilms of the alginate-producing strain. Third, $\mathrm{Ca}^{2+}$ influenced the production of the secreted redox-active compound pyocyanin, which in turn may disrupt calcium homeostasis of epithelial cells (Denning et al., 1998).

Calcium is an important signalling molecule in eukaryotic cells. It also plays a signalling role in bacteria, particularly in the case of secreted proteins (Marquart et al., 2005; Olson \& Ohman, 1992; Sarkisova et al., 2005; Yahr et al., 1997). Since $\mathrm{Ca}^{2+}$ influences biofilm architecture and production of extracellular matrix materials in $P$. aeruginosa, we chose to continue our studies on the physiological differences of biofilm-associated bacteria by investigating the effect of $\mathrm{Ca}^{2+}$ and biofilm growth of the P. aeruginosa cytosolic proteome. Here, we used high-resolution twodimensional gel electrophoresis and algorithms for quantitative 2D gel digital image analysis as tools for discovery of cytosolic proteins influenced by calcium and biofilmassociated growth. We studied the responses of a mucoid CF pulmonary isolate, $P$. aeruginosa FRD1, and compared the results to those for a non-CF strain, PAO1. The goals were (i) to characterize the cytosolic proteome responses to two environmental factors important in CF pathogenesis $\left(\mathrm{Ca}^{2+}\right.$ and biofilm growth), and (ii) to provide strain comparisons between two different and physiologically distinct $P$. aeruginosa isolates. This comparative analysis for a $\mathrm{CF}$ isolate is necessary for a deeper understanding of environmental stimuli and cell responses that drive successful acute and chronic $P$. aeruginosa biofilm infections.

\section{METHODS}

Bacterial strains and media. Pseudomonas aeruginosa FRD1 and PAO1 were used in this study. P. aeruginosa FRD1 is an alginateoverproducing (mucoid) CF pulmonary isolate (Ohman \& Chakrabarty, 1981), and $P$. aeruginosa PAO1 is the non-mucoid strain used for the original genome sequencing study (Stover et al., 2000). Biofilm minimal medium (BMM) contained (per litre): $9.0 \mathrm{mM}$ sodium glutamate, $50 \mathrm{mM}$ glycerol, $0.02 \mathrm{mM} \mathrm{MgSO}_{4}$, $0.15 \mathrm{mM} \mathrm{NaH}{ }_{2} \mathrm{PO}_{4}, 0.34 \mathrm{mM} \mathrm{K} \mathrm{HPO}_{4}, 145 \mathrm{mM} \mathrm{NaCl}, 20 \mu \mathrm{l}$ trace metal solution and $1 \mathrm{ml}$ vitamin solution. Trace metal solution contained (per litre $0.83 \mathrm{M} \mathrm{HCl}$ ): $5.0 \mathrm{~g} \mathrm{CuSO}_{4} .5 \mathrm{H}_{2} \mathrm{O}, 5.0 \mathrm{~g}$ $\mathrm{ZnSO}_{4} .7 \mathrm{H}_{2} \mathrm{O}$, $5.0 \mathrm{~g} \mathrm{FeSO}_{4} \cdot 7 \mathrm{H}_{2} \mathrm{O}$ and $\left.2.0 \mathrm{~g} \mathrm{MnCl}_{2} \cdot 4 \mathrm{H}_{2} \mathrm{O}\right)$. Vitamin solution contained (per litre): $0.5 \mathrm{~g}$ thiamine and $1 \mathrm{mg}$ biotin. The $\mathrm{pH}$ of the medium was adjusted to 7.0 . When required, $\mathrm{CaCl}_{2} \cdot 2 \mathrm{H}_{2} \mathrm{O}$ was added to final concentration of $10.0 \mathrm{mM}$.

Biofilm growth. $P$. aeruginosa biofilms were cultivated on the walls of silicone tubing ( $0.6 \mathrm{~m}$ length, size 18 tubing with an interior volume of $40 \mathrm{ml}$ ), as in experiments described previously (Sarkisova 
et al., 2005; Sauer et al., 2002). Briefly, the system consisted of a single-flow-through system containing a medium reservoir, pump, silicone tubing and a waste container. Prior to inoculation into the system, each strain was incubated in BMM for $16-20 \mathrm{~h}$ at $37^{\circ} \mathrm{C}$. When the cell density reached $1 \times 10^{7}$ cells $\mathrm{ml}^{-1}$, as determined by absorption/scattering, the cultures were diluted to $1 \times 10^{6} \mathrm{cells} \mathrm{ml}^{-1}$ in $0.85 \% \mathrm{NaCl}$. This culture $(2 \mathrm{ml})$ was used to inoculate the tubing flow-cells under quiescent conditions for $20 \mathrm{~min}$. Following inoculation, sterile BMM was pumped through the tubing at a rate of $2 \mathrm{ml} \mathrm{m^{-1 }}$ for $72 \mathrm{~h}$ to allow biofilm growth. Attached cells were removed from the interior surface of the tubing by using the plunger of a $3 \mathrm{ml}$ syringe. Planktonic cultures were incubated in BMM medium at $37^{\circ} \mathrm{C}$ as described previously (Sarkisova et al., 2005). Cells were harvested from $500 \mathrm{ml}$ flasks after $18 \mathrm{~h}$ growth (midexponential phase).

Two-dimensional gel electrophoresis (2DGE) of cellular proteins. Preliminary experiments indicated that most $P$. aeruginosa proteins resolved in the acidic-to-neutral range. Therefore, Pharmalyte and Immobiline Dry-Strips 4-7 (GE Healthcare) were used for isoelectic focusing. Iodacetamide and CHAPS were from Acros Organics and MP Biomedicals, respectively. All chemicals were of analytical grade and used without further purification.

Cells from planktonic and biofilm cultures were obtained as described previously (Sarkisova et al., 2005). Cell pellets were washed twice with saline solution $(0.85 \% \mathrm{NaCl})$ and resuspended in TE buffer $(10 \mathrm{mM}$ Tris/HCl, $1 \mathrm{mM}$ EDTA, $\mathrm{pH} 8.0$, containing $0.3 \mathrm{mg}$ PMSF $\mathrm{ml}^{-1}$ ). Cells were disrupted by sonication ( 12 times for $10 \mathrm{~s}, 4 \mathrm{~W}, 4{ }^{\circ} \mathrm{C}$ ), and the cell debris and unbroken cells were removed by centrifugation $\left(12000 \mathrm{~g}, 60 \mathrm{~min}, 4^{\circ} \mathrm{C}\right.$ ). The protein concentrations of the supernatants were determined by using a modified Lowry assay. Protein samples were stored as aliquots at $-80{ }^{\circ} \mathrm{C}$. Two-dimensional gel electrophoresis was performed as described previously (Sarkisova et al., 2005). Briefly, proteins were loaded by in-gel rehydration into $18 \mathrm{~cm}$ immobilized $\mathrm{pH}$ gradient (IPG) strips with $\mathrm{pH}$ range of 4-7. Solubilization buffer consisted of $9 \mathrm{M}$ urea, $2 \mathrm{M}$ thiourea, $4 \%$ CHAPS, $2 \%(\mathrm{w} / \mathrm{v})$ carrier ampholytes, $0.037 \mathrm{M}$ DTT and a trace amount of bromophenol blue. Isoelectric focusing was conducted using a Multiphor II (Pharmacia) at $20{ }^{\circ} \mathrm{C}$. Proteins were focused for a total of $28 \mathrm{kVh}$. Second-dimension electrophoresis was carried out on $11 \%$ polyacrylamide gels $(230 \times 200 \times 1 \mathrm{~mm})$ using a vertical Hoefer Dalt system (Pharmacia) at $10{ }^{\circ} \mathrm{C}$ using $10 \mathrm{~mA}$ per gel for $4 \mathrm{~h}$, then $40 \mathrm{~mA}$ per gel for $14-16 \mathrm{~h}$. Proteins were detected by colloidal Coomassie staining.

Proteomic analysis. The gels were imaged, and the digital images were analysed by using Progenesis Workstation software (Nonlinear Dynamics). A minimum of two biological replicates were performed for each condition, and the signal intensity of each spot was averaged over the replicates. The signal intensities of protein spots were normalized against total signal intensity detected on a gel. Only the proteins present in all replicates were added to the averaged gel, and only spots with a normalized volume (NV) of 0.01 or greater were analysed further. The averaged proteome profiles obtained for every condition were quantitatively compared. To analyse changes in protein abundance profiles across multiple proteomes, spots and normalized intensity values were imported into GeneSpring GXv7.3.1 software (Agilent Technologies). Normalized protein values were filtered for fold-change; those with at least a twofold change compared to any other sample were selected for cluster analysis. Primary clusters were obtained by hierarchical clustering of both genes and conditions, using a Pearson correlation similarity measure and an average linkage clustering algorithm. Clusters were manually refined on the basis of dominant fold-change differences between experimentally significant groups.
For protein identification we targeted proteins if they met two criteria: (1) the protein had a NV greater than 0.03 , and (2) the proteins were at least threefold more or less abundant in the planktonic or biofilm proteomes cultivated with $10 \mathrm{mM} \mathrm{CaCl}_{2}$ versus their matched counterparts cultivated without added $\mathrm{CaCl}_{2}$. Proteins of interest were excised from the gels and identified based on peptide mass fingerprint analysed on a 4700 MALDI-TOF/TOF mass spectrometer (University of Texas, Biomolecular Resource facility, Mass Spectrometry Laboratory), using the Applied Biosystems GPS (version 3.6) software, MASCOT search engine and NCBInr database. A protein was considered identified if the hit fulfilled four criteria: (1) it was statistically significant (with a MASCOT search score above $75)$, (2) the number of the matched peptides was at least five, (3) the protein sequence coverage was above $20 \%$, and (4) the predicted molecular mass and pI were consistent with the experimentally determined values.

\section{RESULTS AND DISCUSSION}

\section{Biofilm growth and $\left[\mathrm{Ca}^{2+}\right]$ have cumulative effects on the proteomes of $P$. aeruginosa PAO1 and FRD1}

$P$. aeruginosa undergoes physiological changes during its transition from planktonic to biofilm-associated growth and chronic pulmonary infections. Proteomic and transcriptomic studies have been performed previously to study changes in non-mucoid strains during biofilm formation (Sauer et al., 2002; Southey-Pillig et al., 2005; Waite et al., 2005, 2006; Whiteley et al., 2001). In addition, transcriptional profiles have been obtained previously for mucoid P. aeruginosa (Firoved \& Deretic, 2003). Here we present a global proteomic examination comparing an alginate-producing CF lung isolate and a non-mucoid strain of $P$. aeruginosa during growth in planktonic culture and in biofilms. The experiments were performed in minimal medium, so that the effects of additional environmental parameters could be determined. Our previous work identified $\mathrm{Ca}^{2+}$ as influencing biofilm structure of $P$. aeruginosa, and causing changes in the concentration of extracellular biofilm-matrix factors (Sarkisova et al., 2005). Therefore, and for reasons described above, we chose to investigate the effect of $\mathrm{Ca}^{2+}$ on the global cytosolic factors of the two strains during biofilm growth.

Using 2DGE, we resolved on average 630 protein spots in the $\mathrm{pH}$ range 4-7 for the non-mucoid strain, $P$. aeruginosa PAO1, grown either planktonically or in biofilms. The Venn diagram in Fig. 1(a) shows the number of protein spots (352) present under all of four conditions tested (planktonic/ $0 \mathrm{mM} \mathrm{CaCl}_{2}$, planktonic/10 $\mathrm{mM} \mathrm{CaCl}_{2}$, biofilm/0 $\mathrm{mM} \mathrm{CaCl} 2$, and biofilm/10 $\mathrm{mM} \mathrm{CaCl}_{2}$, labelled P-0, P-10, B-0 and B-10, respectively). Also shown in Fig. 1(a) are the numbers of unique protein spots expressed only under one condition or under overlapping conditions. Biofilm growth showed the greatest number of unique protein spots at both low and high $\left[\mathrm{Ca}^{2+}\right]$, demonstrating that biofilm growth results in significant physiological effects on the P. aeruginosa PAO1 proteome, and confirming previous reports on $P$. aeruginosa biofilm formation 

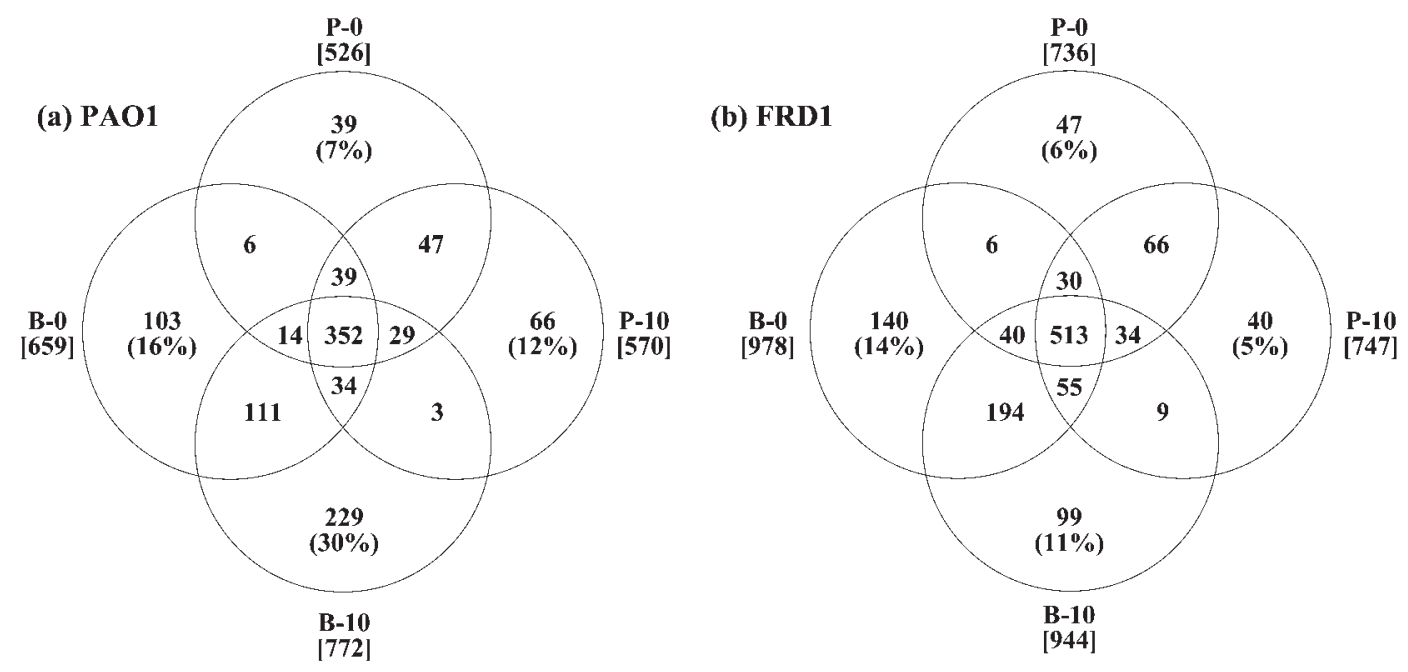

Fig. 1. Venn diagrams representing comparisons of the cytosolic proteomes of (a) P. aeruginosa PAO1 and (b) FRD1. Each circle represents a different growth condition. The numbers of unique protein spots, found for only one condition or for the overlapping conditions, are shown. Conditions include biofilm-associated growth with no added $\mathrm{CaCl}_{2}(\mathrm{~B}-0)$ or with $10 \mathrm{mM}$ added $\mathrm{CaCl}_{2}$ (B-10), and planktonic growth with no added $\mathrm{CaCl}_{2}(\mathrm{P}-0)$ or with $10 \mathrm{mM} \mathrm{CaCl}_{2}(\mathrm{P}-10)$. The numbers in square brackets are the total numbers of protein spots detected on duplicate gels for the same conditions. The numbers in parentheses are the percentages of spots that are unique to one particular condition.

(Sauer et al., 2002). Pairwise comparison showed that of the four proteomes, the two biofilm proteomes (B-0 and B-10) were most similar to each other, sharing $81 \%$ of protein spots. The two planktonic proteomes were also similar to each other, sharing $74 \%$ of the proteins. In contrast, the least similar to each other were the planktonic proteome at $0 \mathrm{mM} \mathrm{CaCl}$ and the biofilm proteome at $10 \mathrm{mM} \mathrm{CaCl}_{2}$, which only shared $63 \%$ of their proteins.

We observed a similar global proteome response to biofilm growth and to $\mathrm{Ca}^{2+}$ for the mucoid CF isolate, $P$. aeruginosa FRD1, demonstrating that even though the mucoid strain is encapsulated in alginate, in both planktonic and biofilm culture, it is nonetheless able to respond to growth associated with a surface and dramatically change its cytosolic proteome. For this strain we resolved an average of 850 protein spots in the proteomes of planktonic and biofilm cultures (Fig. 1b). Of these protein spots, 513 proteins were detected under all four conditions. The individual conditions resulted in 40-140 unique proteins. As with the $\mathrm{PAO} 1$ proteomes, pair-wise comparisons showed that the most similar proteome pair was the two biofilm cultures (B-0 and B-10), which shared $94 \%$ of the proteins. The two planktonic cultures (P-0 and P-10) were similar to each other, sharing $76 \%$ of the proteins. However, the biofilm cultures shared only 69 $72 \%$ of the proteins with their planktonic counterparts.

To estimate how many proteins in the P. aeruginosa PAO1 proteomes had changed abundances of at least twofold (including unique proteins) under the effect of $\left[\mathrm{Ca}^{2+}\right]$ or biofilm growth, we quantitatively compared protein spot intensities in proteome pairs. Fig. 2 shows that although biofilm growth had the greatest effect on the number of proteins with at least twofold differences in abundances (51-54\% of proteins), $\left[\mathrm{Ca}^{2+}\right]$ contributed to this effect. Whereas in planktonic culture, $\left[\mathrm{Ca}^{2+}\right]$ resulted in

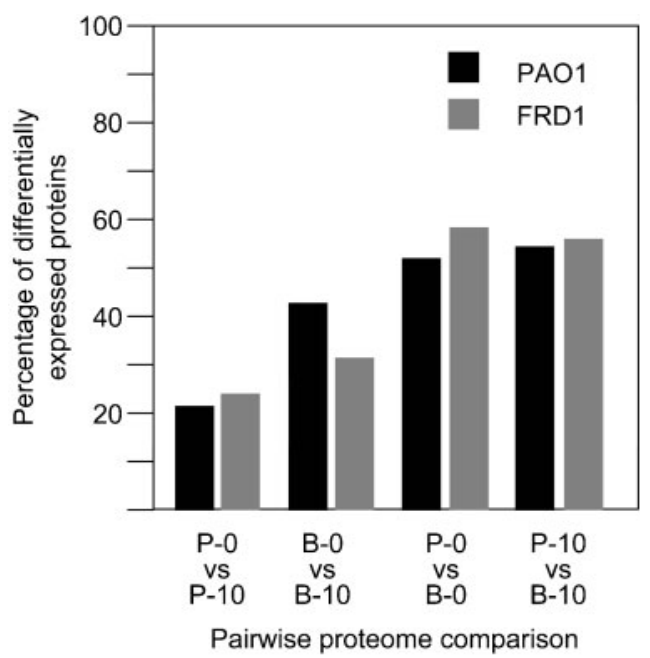

Fig. 2. Quantitative comparison of protein abundances in proteome pairs. The percentages of proteins with twofold more or less abundance compared to the total number of proteins detected are shown. The percentages correspond to averaged gels (obtained by using Progenesis software) for at least two biological replicates for each condition. Proteome comparisons are for planktonic and biofilm-associated growth with or without added $\mathrm{CaCl}_{2}$, labelled as in Fig. 1 . 
differential abundances of $23 \%$ of proteins, this increased to $43 \%$ in biofilm cultures, demonstrating that $\left[\mathrm{Ca}^{2+}\right]$ and biofilm growth have cumulative effects on the proteomes of $P$. aeruginosa PAO1. Similar results were observed in the pair-wise comparison of the $P$. aeruginosa FRD1 proteomes. Quantitative comparison of the spot intensities in proteome pairs showed that the number of differentially expressed proteins reached its highest level $(56-60 \%)$ in the biofilm proteomes versus their planktonic counterparts. $\left[\mathrm{Ca}^{2+}\right]$ contributed to this effect primarily during biofilm growth.

\section{Cluster analysis of protein abundance profiles reveals changes in response of individual proteins to environmental conditions}

To characterize the responses of individual proteins to changes in environmental conditions, the normalized signal intensities of 568 differentially expressed proteins from PAO1 and 897 proteins from FRD1 were analysed by hierarchical cluster analysis. Protein spot signal intensities generated by Progenesis software were imported into GeneSpring software. Proteins were clustered based on abundance patterns for each protein under the different growth conditions. For both strains, 12 clusters were identified, including 377 proteins from PAO1, representing $66 \%$ of the differentially expressed proteins, and 554 proteins from FRD1, constituting $62 \%$ of the differentially expressed proteins (Fig. 3). Clusters 1-3 combine the proteins that were more abundant during biofilm growth, either independently of $\left[\mathrm{Ca}^{2+}\right]$ (cluster 1 ) or at low $\left[\mathrm{Ca}^{2+}\right]$ (cluster 2), or high $\left[\mathrm{Ca}^{2+}\right]$ (cluster 3). Clusters 4-6 include the proteins that have greater abundances during planktonic growth, either independently of $\left[\mathrm{Ca}^{2+}\right]$ (cluster 4) or at low (cluster 5) or high $\left[\mathrm{Ca}^{2+}\right]$ (cluster 6). Clusters 7 and 8 contain proteins that are influenced by $\left[\mathrm{Ca}^{2+}\right]$, but not influenced by biofilm growth. The remaining clusters contain proteins that are reduced under one condition (cluster 9, reduced in B-0; cluster 10, reduced in B-10; cluster 11, reduced in P-0; and cluster 12, reduced in P-10).

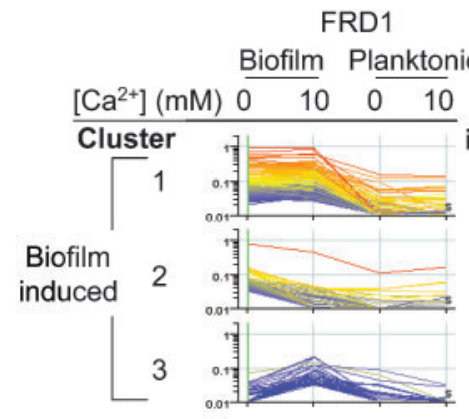

Percent
in cluster
29
14
7

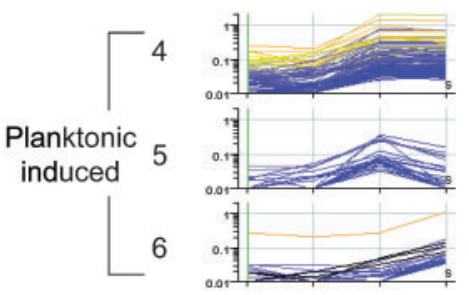

5

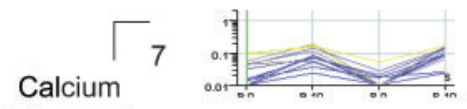
influenced

\section{8}

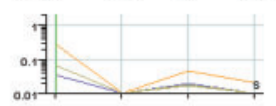

2

1

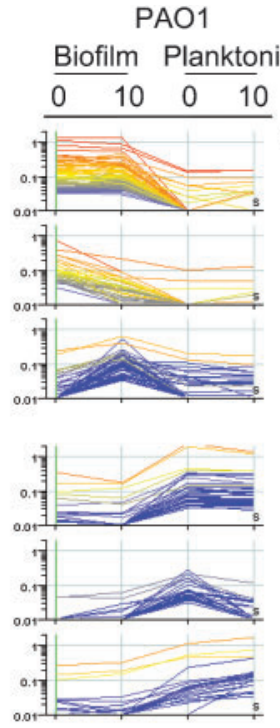

tonic

in cluster

20

10

15

11

9

6

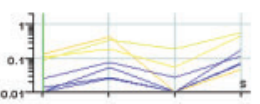

2

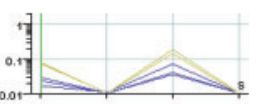

1

3

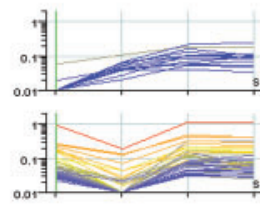

3

10

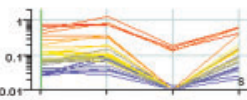

8

2

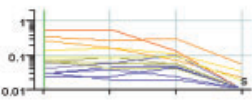

Fig. 3. Hierarchical cluster analysis of proteinspot signal intensities for the FRD1 and PAO1 proteomes. Signal intensities from averaged duplicate samples were obtained by using Progenesis software for each protein under the four conditions tested (planktonic growth at low and high $\left[\mathrm{CaCl}_{2}\right]$ and biofilm growth at low and high $\left.\left[\mathrm{CaCl}_{2}\right]\right)$. Signal intensities were exported from Progenesis Software into GeneSpring Software for cluster analysis. Proteins with similar signal intensity patterns under the four conditions were clustered together, and 12 clusters were obtained for each strain. Signal intensities for 554 proteins from FRD1 and 377 proteins from PAO1, and the percentages of proteins that grouped into each of the 12 clusters, are shown. The colours correspond to protein abundances, with red showing greatest abundance, yellow intermediate levels and blue lower abundance. 
In both PAO1 and FRD1 most differentially expressed proteins (45-50\%) were represented in clusters 1-3 (biofilm-induced clusters), with approximately $30 \%$ of the proteins represented in the planktonic-induced clusters (clusters 4-6). Three per cent of the proteins were positively or negatively affected by calcium independently of biofilm growth (clusters 7 and 8, respectively). The remaining proteins ( $25 \%$ in PAO1 and $15 \%$ in FRD1) had decreased abundance in response to one of the four conditions. Cluster analysis was used to identify protein spots most suitable for protein identification by mass spectrometry. From the PAO1 proteomes we identified 59 protein spots, including 46 unique proteins. These proteins represented eight of the 12 clusters described above. We also identified 140 proteins from the FRD1 proteomes (including 100 unique proteins) representing nine of the 12 clusters. Table 1 lists 45 proteins whose abundances were influenced by biofilmassociated growth and/or by $\left[\mathrm{Ca}^{2+}\right]$, and the cluster for each protein.

\section{Biofilm-induced synthesis of proteins involved in iron acquisition and storage}

The level of intracellular iron or active transport of chelated iron serves as a signal for biofilm development in P. aeruginosa PAO1 (Banin et al., 2005) and is critical for $P$. aeruginosa virulence (Musk et al., 2005). For example, iron bound to the $P$. aeruginosa-derived siderophore pyochelin augments oxidant-mediated damage to pulmonary artery endothelial cells (Britigan et al., 1992, 1994). Here, we identified a number of proteins involved in iron acquisition and storage that were induced by biofilm growth and/or by $\left[\mathrm{Ca}^{2+}\right]$. Four proteins involved in the two iron-acquisition systems, PvdNOA (the high-affinity pyoverdine system) and FptA (the low-affinity pyochelin receptor protein) (Redly \& Poole, 2003), shared similar abundance profiles in PAO1, highly induced by $\mathrm{Ca}^{2+}$ during biofilm growth (cluster 3). Southey-Pillig et al. (2005) also showed the presence of Pvd proteins in the proteomes of PAO1 cells at the first (PvdSQA) and second (PvdDJL) stages of biofilm maturation. Therefore, these results for PAO1 are consistent with previous reports. However, our data show that $\left[\mathrm{Ca}^{2+}\right]$ in addition to biofilm growth contributes to the induction of these two siderophore systems (e.g. PvdN; Fig. 4). Interestingly, in FRD1, abundances of Pvd and Fpt proteins differed from those in PAO1. No detectable amounts of FptA or PvdA were seen under any of the conditions tested. However, PvdNO showed no effect due to biofilm growth, but had greater abundance due to increased $\left[\mathrm{Ca}^{2+}\right]$ (cluster 7; Fig. 4).

Although the siderophore-mediated iron acquisition systems varied in expression between the strains, other iron uptake proteins were similar. Bacterioferritin (BfrA) and ViuB (PA2033), a protein predicted to interact with siderophores, were highly expressed in biofilms, independently of $\left[\mathrm{Ca}^{2+}\right]$ (cluster 1; Fig. 4).
A bacterioferritin homologue, PA4880, was highly expressed in FRD1 biofilms (cluster 1) but not observed in PAO1. Two other proteins, HitA (PA4687) and PA5217, both of which are probably involved in iron transport, were induced by $\mathrm{Ca}^{2+}$ in both planktonic and biofilm cultures of PAO1 (cluster 7) and had reduced abundance in biofilms of FRD1 (cluster 4).

Biosynthesis and secretion of pyoverdine are regulated by means of the extracytoplasmic function (ECF) $\sigma$ factor $\mathrm{PvdS}$, whose expression is regulated by iron concentration and the ferric uptake regulator (Fur) (Hassett et al., 1996; Ochsner et al., 1995; Ochsner \& Vasil, 1996; Vasil et al., 1998). Our results demonstrate that $\left[\mathrm{Ca}^{2+}\right]$ influences the production of iron-scavenging proteins and products, but the role of $\left[\mathrm{Ca}^{2+}\right]$ in this process is not clear. Calcium may play a direct role in signalling production of these proteins, but it may also have an indirect effect by causing an increase in thickness of biofilms. This effect may be more pronounced in FRD1, where $\mathrm{Ca}^{2+}$ causes a more dramatic effect on biofilm thickness (Sarkisova et al., 2005), and perhaps results in a higher percentage of biofilm-associated cells undergoing iron starvation. These results confirm the importance of iron and iron scavenging in $P$. aeruginosa biofilm development, as both strains produced ironacquiring proteins and siderophores during this process. The strains varied in the particular iron-acquiring proteins produced.

\section{Quorum sensing and quinolone signalling}

Quorum sensing is an important component in the development of $P$. aeruginosa biofilms (Davies et al., 1998). Many of the proteins we identified as having increased abundances in biofilms are regulated by the LasR and/or RhlR quorum-sensing regulators (Table 1). In addition, we identified PqsB protein, involved in biosynthesis of Pseudomonas quinolone signal (PQS), a third $P$. aeruginosa signalling compound, as increased in abundance in FRD1 biofilms (Fig. 4). The abundance of PqsB was relatively constant under the different growth conditions for PAO1, although twofold higher in planktonic culture at high $\left[\mathrm{Ca}^{2+}\right]$. Quinolone signalling has been shown to be involved in the regulation of iron-starvation-responsive genes, possibly through its ability to chelate iron (Bredenbruch et al., 2006), and therefore may influence the production of iron-scavenging proteins as observed above. It is also involved in regulation of certain stressresponsive genes; and in FRD1, protein abundances of a number of stress-responsive genes correlated with the abundance of PqsB (Table 1 and described below).

\section{Biofilm growth affects the abundance of proteins involved in oxidative stress and protein post- translational modification}

Oxidative stress has been reported previously to be interlinked with iron availability (Hassett et al., 1995, 
Table 1. Proteins identified by MASCOT-based analysis of MALDI-TOF-generated mass spectra

\begin{tabular}{|c|c|c|c|c|c|c|c|c|c|c|c|c|c|c|c|}
\hline \multirow[t]{3}{*}{ Protein name } & \multirow{3}{*}{$\begin{array}{l}\text { Gene } \\
\text { name }\end{array}$} & \multirow{3}{*}{$\begin{array}{l}\text { PA } \\
\text { no. }\end{array}$} & \multirow{3}{*}{$\begin{array}{l}\text { Genetic } \\
\text { context }\end{array}$} & \multirow{3}{*}{$\begin{array}{l}\text { Cluster } \\
\text { PAO1/ } \\
\text { FRD1 }\end{array}$} & \multirow{3}{*}{$\begin{array}{l}\text { MASCOT } \\
\text { score }^{\star}\end{array}$} & \multirow{3}{*}{$\begin{array}{c}\text { No. of } \\
\text { peptides } \\
\text { matched }\end{array}$} & \multirow{3}{*}{$\begin{array}{l}\text { Regulated } \\
\text { by QS } \dagger\end{array}$} & \multicolumn{8}{|c|}{ Normalized signal intensity (NV) $\ddagger$} \\
\hline & & & & & & & & \multicolumn{4}{|c|}{ PAO1 } & \multicolumn{4}{|c|}{ FRD1 } \\
\hline & & & & & & & & P-0 & P-10 & B-0 & B-10 & P-0 & P-10 & B-0 & B-10 \\
\hline \multicolumn{16}{|l|}{$\begin{array}{l}\text { Iron acquisition } \\
\text { and storage }\end{array}$} \\
\hline PvdN & $p v d N$ & 2394 & $\begin{array}{l}\text { pvd, } \\
\text { pyoverdine } \\
\text { synthesis } \\
\text { operon }\end{array}$ & $3 / 7$ & 481 & 16 & & $\mathrm{~N}$ & $\mathrm{~N}$ & 0.065 & 0.19 & 0.019 & 0.046 & 0.007 & 0.019 \\
\hline PvdO & $p v d O$ & 2395 & pvd operon & $3 / 7$ & 104 & 10 & & 0.078 & 0.087 & 0.051 & 0.13 & $\mathrm{~N}$ & 0.15 & $\mathrm{~N}$ & 0.087 \\
\hline $\begin{array}{l}\text { PvdA, } \\
\text { L-ornithine } \\
N^{5} \text {-oxygenase }\end{array}$ & $p v d A$ & 2386 & pvd operon & $3 / \mathrm{N}$ & 304 & 18 & $\mathrm{P}$ & $\mathrm{N}$ & $\mathrm{N}$ & $\mathrm{N}$ & 0.048 & $\mathrm{~N}$ & $\mathrm{~N}$ & $\mathrm{~N}$ & $\mathrm{~N}$ \\
\hline $\begin{array}{l}\mathrm{Fe}(\mathrm{III}) \text {-pyochelin } \\
\text { receptor } \\
\text { precursor }\end{array}$ & $f p t A$ & 4221 & $\begin{array}{l}\text { fptAB and } \\
\text { pchEFR, } \\
\text { pyochelin } \\
\text { synthesis } \\
\text { operon }\end{array}$ & $3 / \mathrm{N}$ & 278 & 21 & $\mathrm{P}$ & $\mathrm{N}$ & $\mathrm{N}$ & $\mathrm{N}$ & 0.19 & $\mathrm{~N}$ & $\mathrm{~N}$ & $\mathrm{~N}$ & $\mathrm{~N}$ \\
\hline $\begin{array}{l}\text { Hypothetical } \\
\text { protein } \\
\text { (predicted } \\
\text { siderophore- } \\
\text { interacting } \\
\text { protein) }\end{array}$ & $\begin{array}{l}\text { Predicted } \\
\quad v i u B\end{array}$ & 2033 & Single gene & $1 / 1$ & 101 & 10 & & 0.03 & 0.033 & 0.073 & 0.20 & 0.031 & 0.09 & 0.16 & 0.15 \\
\hline Bacterioferritin & $b f r A$ & 4235 & katA & $1 / 1$ & 198 & 9 & & $\mathrm{~N}$ & $\mathrm{~N}$ & 0.08 & 0.31 & $\mathrm{~N}$ & $\mathrm{~N}$ & 0.21 & 0.13 \\
\hline $\begin{array}{l}\text { Probable } \\
\text { bacterioferritin }\end{array}$ & & 4880 & Single gene & $\mathrm{N} / 1$ & 75 & 9 & $P, L, R$ & $\mathrm{~N}$ & $\mathrm{~N}$ & $\mathrm{~N}$ & $\mathrm{~N}$ & $\mathrm{~N}$ & $\mathrm{~N}$ & 0.38 & 0.23 \\
\hline $\begin{array}{l}\text { Ferric iron-binding } \\
\text { periplasmic } \\
\text { protein HitA }\end{array}$ & hitA & 4687 & hitB & $7 / 4$ & 320 & 12 & & 0.053 & 0.16 & 0.11 & 0.19 & 0.19 & 0.19 & 0.085 & 0.12 \\
\hline $\begin{array}{l}\text { Probable binding } \\
\text { protein com- } \\
\text { ponent of } \mathrm{ABC} \\
\text { iron transporter }\end{array}$ & & 5217 & $\begin{array}{l}\text { ABC iron } \\
\text { transport } \\
\text { and glycine } \\
\text { cleavage } \\
\text { system }\end{array}$ & $7 / 4$ & 198 & 15 & & 0.027 & 0.11 & 0.025 & 0.075 & 0.067 & 0.054 & $\mathrm{~N}$ & 0.019 \\
\hline \multicolumn{16}{|l|}{$\begin{array}{l}\text { Quinolone } \\
\text { signal response }\end{array}$} \\
\hline $\begin{array}{l}\text { Probable } \beta \text {-keto- } \\
\text { acyl-acyl-carrier } \\
\text { protein synthase } \\
\text { Oxidative stress }\end{array}$ & $p q s B$ & 0997 & $\begin{array}{l}p q s A B C D E \\
\text { operon }\end{array}$ & $6 / 1$ & 186 & 7 & $\mathrm{P}, \mathrm{L}, \mathrm{R}$ & 0.059 & 0.11 & 0.063 & 0.047 & 0.044 & 0.04 & 0.09 & 0.12 \\
\hline Catalase & katA & 4236 & $b f r A$ & $1 / 11$ & 323 & 20 & $\mathrm{P}$ & $\mathrm{N}$ & 0.01 & 0.044 & 0.07 & 0.014 & 0.031 & 0.063 & 0.07 \\
\hline Catalase HPII & katE & 2147 & Hypothetical & $\mathrm{N} / 4$ & 331 & 23 & $\mathrm{P}, \mathrm{L}, \mathrm{R}$ & $\mathrm{N}$ & $\mathrm{N}$ & $\mathrm{N}$ & $\mathrm{N}$ & 0.25 & 0.25 & 0.044 & 0.042 \\
\hline $\begin{array}{l}\text { Alkyl } \\
\text { hydroperoxide } \\
\text { reductase } \\
\text { subunit C }\end{array}$ & $\operatorname{ahpC}$ & 0139 & $a h p F$ & $7 / 4$ & 264 & 9 & $\mathrm{P}$ & 0.13 & 0.61 & 0.43 & 0.82 & 0.43 & 0.45 & 0.29 & 0.29 \\
\hline $\begin{array}{l}\text { Probable } \\
\text { peroxidase }\end{array}$ & & 3529 & Single gene & $3 / \mathrm{N}$ & 176 & 17 & & $\mathrm{~N}$ & $\mathrm{~N}$ & $\mathrm{~N}$ & 0.14 & $\mathrm{~N}$ & $\mathrm{~N}$ & $\mathrm{~N}$ & $\mathrm{~N}$ \\
\hline $\begin{array}{l}\text { Probable } \\
\text { antioxidant } \\
\text { protein }\end{array}$ & & 3450 & Single gene & $2 / \mathrm{N}$ & 311 & 12 & & $\mathrm{~N}$ & $\mathrm{~N}$ & 0.096 & 0.005 & $\mathrm{~N}$ & $\mathrm{~N}$ & $\mathrm{~N}$ & $\mathrm{~N}$ \\
\hline
\end{tabular}


Table 1. cont.

\begin{tabular}{|c|c|c|c|c|c|c|c|c|c|c|c|c|c|c|c|}
\hline \multirow[t]{2}{*}{ Protein name } & \multirow{2}{*}{$\begin{array}{l}\text { Gene } \\
\text { name }\end{array}$} & \multirow{2}{*}{$\begin{array}{l}\text { PA } \\
\text { no. }\end{array}$} & \multirow{2}{*}{$\begin{array}{l}\text { Genetic } \\
\text { context }\end{array}$} & \multirow{2}{*}{$\begin{array}{l}\text { Cluster I } \\
\text { PAO1/ } \\
\text { FRD1 }\end{array}$} & \multirow{2}{*}{$\begin{array}{l}\text { MASCOT } \\
\text { score }^{\star}\end{array}$} & \multirow{2}{*}{$\begin{array}{l}\text { No. of } \\
\text { peptides } \\
\text { matched }\end{array}$} & \multirow{2}{*}{$\begin{array}{l}\text { Regulated } \\
\text { by QS } \dagger\end{array}$} & \multicolumn{8}{|c|}{ Normalized signal intensity $(\mathrm{NV}) \ddagger$} \\
\hline & & & & & & & & \multicolumn{4}{|c|}{ PAO1 } & \multicolumn{4}{|c|}{ FRD1 } \\
\hline \multicolumn{16}{|l|}{$\begin{array}{l}\mathrm{PTM} / \text { chaperones/ } \\
\text { stress response }\end{array}$} \\
\hline $\begin{array}{l}\text { Predicted universal } \\
\text { stress protein } \\
\text { UspA }\end{array}$ & & 4352 & 2 Hypothetical & $1 / 1$ & 634 & 21 & & 0.092 & 0.096 & 0.22 & 0.18 & $\mathrm{~N}$ & $\mathrm{~N}$ & 0.25 & 0.21 \\
\hline $\begin{array}{l}\text { Predicted universal } \\
\text { stress protein } \\
\text { UspA }\end{array}$ & & 3309 & $\begin{array}{l}\text { RNA helicase } \\
\text { hepA }\end{array}$ & $1 / 1$ & 582 & 15 & & $\mathrm{~N}$ & $\mathrm{~N}$ & 0.58 & 0.53 & $\mathrm{~N}$ & $\mathrm{~N}$ & 0.67 & 0.81 \\
\hline DnaK protein & $d n a K$ & 4761 & $\begin{array}{l}\text { dnaJ, grpE, } \\
\text { dapB }\end{array}$ & $3 / 1$ & 159 & 20 & $\mathrm{P}$ & $\mathrm{N}$ & $\mathrm{N}$ & $\mathrm{N}$ & 0.11 & 0.024 & 0.027 & 0.077 & 0.066 \\
\hline Trigger factor & tig & 1800 & $\begin{array}{l}\text { clpPX } \\
\text { proteases }\end{array}$ & $3 / \mathrm{N}$ & 128 & 10 & & $\mathrm{~N}$ & $\mathrm{~N}$ & $\mathrm{~N}$ & 0.12 & $\mathrm{~N}$ & $\mathrm{~N}$ & $\mathrm{~N}$ & $\mathrm{~N}$ \\
\hline $\begin{array}{l}\text { Heat-shock } \\
\text { protein HtpG }\end{array}$ & $h t p G$ & 1596 & 5 Hypothetical & $3 / \mathrm{N}$ & 285 & 24 & & $\mathrm{~N}$ & $\mathrm{~N}$ & $\mathrm{~N}$ & 0.07 & $\mathrm{~N}$ & $\mathrm{~N}$ & $\mathrm{~N}$ & $\mathrm{~N}$ \\
\hline $\begin{array}{l}\text { Thiol: disulfide } \\
\text { interchange } \\
\text { protein DsbA }\end{array}$ & $d s b A$ & 5489 & Hypothetical & $11 / 4$ & 557 & 11 & & 0.08 & 0.18 & 0.19 & 0.25 & 0.44 & 0.39 & 0.065 & 0.12 \\
\hline $\begin{array}{l}\text { PvdS-regulated } \\
\text { endoprotease, } \\
\text { lysyl class }\end{array}$ & $\operatorname{prpL}$ & 4175 & Single gene & $1 / 1$ & 202 & 10 & $\mathrm{~L}, \mathrm{R}$ & $\mathrm{N}$ & $\mathrm{N}$ & 0.26 & 0.33 & $\mathrm{~N}$ & 0.044 & 0.17 & 0.17 \\
\hline $\begin{array}{l}\text { ATP-dependent } \\
\text { Clp protease } \\
\text { proteolytic } \\
\text { subunit }\end{array}$ & $c l p P$ & 1801 & I tig-clpX & $11 / 1$ & 128 & 10 & & 0.092 & 0.13 & 0.19 & 0.23 & 0.071 & 0.088 & 0.19 & 0.19 \\
\hline $\begin{array}{r}\text { Predicted } \\
\text { protease }\end{array}$ & thiJ & 1135 & 5 Hypothetical & $7 / 4$ & 128 & 10 & & 0.012 & 0.025 & 0.026 & 0.095 & 0.046 & 0.059 & 0.029 & 0.01 \\
\hline Protease PfpI & $p f p I$ & 0355 & 5 Hypothetical & $7 / 4$ & 496 & 10 & L, R & 0.057 & 0.091 & 0.045 & 0.14 & 0.33 & 0.27 & 0.037 & 0.06 \\
\hline $\begin{array}{l}\text { Probable } \\
\text { protease }\end{array}$ & & 4171 & I Hypothetical & $\mathrm{N} / 4$ & 235 & 8 & $\mathrm{~L}, \mathrm{R}$ & $\mathrm{N}$ & $\mathrm{N}$ & $\mathrm{N}$ & $\mathrm{N}$ & 0.2 & 0.12 & $\mathrm{~N}$ & $\mathrm{~N}$ \\
\hline \multicolumn{16}{|l|}{$\begin{array}{l}\text { Phenazine } \\
\text { biosynthesis }\end{array}$} \\
\hline $\begin{array}{l}\text { Probable } \\
\text { phenazine } \\
\text { biosynthesis } \\
\text { protein }\end{array}$ & phzB1 & 4211 & $\begin{array}{l}\text { Phenazine } \\
\text { biosynthesis } \\
\text { (phz) } \\
\text { operon }\end{array}$ & $1 / 1$ & 108 & 8 & $\mathrm{~L}, \mathrm{R}$ & $\mathrm{N}$ & $\mathrm{N}$ & 0.17 & 0.088 & $\mathrm{~N}$ & $\mathrm{~N}$ & 0.24 & 0.19 \\
\hline
\end{tabular}


Table 1. cont.

\begin{tabular}{|c|c|c|c|c|c|c|c|c|c|c|c|c|c|c|c|}
\hline \multirow[t]{3}{*}{ Protein name } & \multirow{3}{*}{$\begin{array}{l}\text { Gene } \\
\text { name }\end{array}$} & \multirow{3}{*}{$\begin{array}{l}\text { PA } \\
\text { no. }\end{array}$} & \multirow{3}{*}{$\begin{array}{l}\text { Genetic } \\
\text { context }\end{array}$} & \multirow{3}{*}{$\begin{array}{l}\text { Cluster } \\
\text { PAO1/ } \\
\text { FRD1 }\end{array}$} & \multirow{3}{*}{$\begin{array}{l}\text { MASCOT } \\
\text { score }^{\star}\end{array}$} & \multirow{3}{*}{$\begin{array}{l}\text { No. of } \\
\text { peptides } \\
\text { matched }\end{array}$} & \multirow{3}{*}{$\begin{array}{l}\text { Regulated } \\
\text { by QS } \dagger\end{array}$} & \multicolumn{8}{|c|}{ Normalized signal intensity (NV) $\ddagger$} \\
\hline & & & & & & & & \multicolumn{4}{|c|}{ PAO1 } & \multicolumn{4}{|c|}{ FRD1 } \\
\hline & & & & & & & & P-0 & P-10 & B-0 & B-10 & P-0 & P-10 & B-0 & B-10 \\
\hline $\begin{array}{l}\text { Probable } \\
\text { phenazine } \\
\text { biosynthesis } \\
\text { protein }\end{array}$ & $p h z F 1$ & 4215 & phz operon & $1 / 1$ & 230 & 7 & $\mathrm{~L}, \mathrm{R}$ & 0.078 & 0.087 & 0.19 & 0.097 & $\mathrm{~N}$ & $\mathrm{~N}$ & 0.28 & 0.27 \\
\hline $\begin{array}{l}\text { Probable } \\
\text { pyridoxamine } \\
5^{\prime} \text {-phosphate } \\
\text { oxidase }\end{array}$ & phzG1 & 4216 & phz operon & $1 / 1$ & 340 & 9 & $\mathrm{~L}, \mathrm{R}$ & $\mathrm{N}$ & $\mathrm{N}$ & 0.03 & 0.25 & $\mathrm{~N}$ & $\mathrm{~N}$ & 0.027 & 0.03 \\
\hline $\begin{array}{l}\text { Flavin-containing } \\
\text { monooxygenase }\end{array}$ & $p h z S$ & 4217 & phz operon & $1 / 1$ & 345 & 17 & $\mathrm{P}, \mathrm{L}, \mathrm{R}$ & $\mathrm{N}$ & 0.012 & 0.21 & 0.042 & 0.007 & 0.037 & 0.096 & 0.14 \\
\hline $\begin{array}{l}\text { Phenazine } \\
\text { biosynthesis } \\
\text { protein PhzD }\end{array}$ & phzD1 & 4213 & phz operon & $1 / 1$ & 215 & 8 & $\mathrm{~L}, \mathrm{R}$ & $\mathrm{N}$ & 0.023 & 0.097 & 0.20 & $\mathrm{~N}$ & $\mathrm{~N}$ & 0.14 & 0.28 \\
\hline $\begin{array}{l}\text { Probable } \\
\text { phenazine } \\
\text { biosynthesis } \\
\text { protein }\end{array}$ & phzB2 & 1900 & phz operon & $1 / 1$ & 196 & 9 & $\mathrm{P}$ & $\mathrm{N}$ & $\mathrm{N}$ & 0.72 & 0.61 & $\mathrm{~N}$ & $\mathrm{~N}$ & 0.24 & 0.19 \\
\hline $\begin{array}{l}\text { Probable } \\
\text { pyridoxamine } \\
5^{\prime} \text {-phosphate } \\
\text { oxidase }\end{array}$ & phzG2 & 1905 & phz operon & $1 / 1$ & 454 & 10 & $\mathrm{P}, \mathrm{L}, \mathrm{R}$ & $\mathrm{N}$ & $\mathrm{N}$ & 0.42 & 0.21 & $\mathrm{~N}$ & $\mathrm{~N}$ & 0.52 & 0.55 \\
\hline \multicolumn{16}{|l|}{$\begin{array}{l}\text { Polysaccharide } \\
\text { biosynthesis/ } \\
\text { metabolism }\end{array}$} \\
\hline $\begin{array}{l}\text { GDP-mannose } \\
\text { 6-dehydrogenase } \\
\text { AlgD }\end{array}$ & $\operatorname{alg} D$ & 3540 & $\begin{array}{l}\text { Alginate } \\
\text { biosynthesis } \\
\text { operon, alg }\end{array}$ & $\mathrm{N} / 7$ & 505 & 25 & & $\mathrm{~N}$ & $\mathrm{~N}$ & $\mathrm{~N}$ & $\mathrm{~N}$ & 0.2 & 0.52 & 0.30 & 0.75 \\
\hline $\begin{array}{l}\text { Serine protease } \\
\text { MucD } \\
\text { precursor }\end{array}$ & $m u c D$ & 0766 & $\begin{array}{l}\text { Alginate } \\
\text { regulation } \\
\text { operon, } \\
m u c A B C\end{array}$ & $10 / 4$ & 248 & 11 & & 0.075 & 0.094 & 0.094 & 0.055 & 0.15 & 0.17 & 0.036 & 0.054 \\
\hline $\begin{array}{l}\text { UTP-glucose-1- } \\
\text { phosphate } \\
\text { uridylyltransferase }\end{array}$ & galU & 2023 & $\begin{array}{l}\text { Nucleotide } \\
\text { sugar dehy- } \\
\text { drogenase }\end{array}$ & $4 / 4$ & 311 & 12 & & 1.9 & 1.2 & 0.17 & $\mathrm{~N}$ & 1.5 & 1.3 & 0.24 & 0.19 \\
\hline $\begin{array}{l}\text { Probable glycosyl } \\
\text { hydrolase }\end{array}$ & $\operatorname{glg} X$ & 2160 & Hypothetical & $3 / 5$ & 142 & 17 & $\mathrm{~L}, \mathrm{R}$ & $\mathrm{N}$ & $\mathrm{N}$ & 0.012 & 0.077 & 0.7 & 0.034 & $\mathrm{~N}$ & $\mathrm{~N}$ \\
\hline $\begin{array}{l}\text { Glycogen } \\
\text { phosphorylase }\end{array}$ & $\operatorname{glg} P$ & 2144 & Hypothetical & $\mathrm{N} / 4$ & 744 & 36 & $\mathrm{~L}, \mathrm{R}$ & $\mathrm{N}$ & $\mathrm{N}$ & $\mathrm{N}$ & $\mathrm{N}$ & 0.17 & 0.097 & 0.01 & 0.01 \\
\hline \multicolumn{16}{|l|}{$\begin{array}{l}\text { Nitrogen } \\
\text { metabolism }\end{array}$} \\
\hline $\begin{array}{l}\text { NosF protein } \\
\text { nitrous oxide } \\
\text { reductase }\end{array}$ & nos $F$ & 3394 & nosLYFDZR & $3 / 1$ & 75 & 11 & & $\mathrm{~N}$ & $\mathrm{~N}$ & $\mathrm{~N}$ & 0.023 & $\mathrm{~N}$ & $\mathrm{~N}$ & 0.08 & 0.061 \\
\hline Urease $\beta$ subunit & ureB & 4867 & ureDABC & $2 / 1$ & 75 & 5 & & $\mathrm{~N}$ & $\mathrm{~N}$ & 0.093 & 0.008 & $\mathrm{~N}$ & $\mathrm{~N}$ & 0.064 & 0.076 \\
\hline
\end{tabular}

$\mathrm{N}$, not detected.

${ }^{*}$ MASCOT-generated probability-based Mowse score. Scores greater than 75 are significant $(P<0.05)$.

$\dagger$ The corresponding genes were reported as being upregulated by LasI (L), RhlI (R) or PQS (P) quorum sensing (QS) systems in Bredenbruch et al. (2006), Schuster et al. (2003) or Wagner et al. (2003).

$\ddagger$ Average normalized volumes over the two biological replicates under each of the tested growth conditions. 
PA01

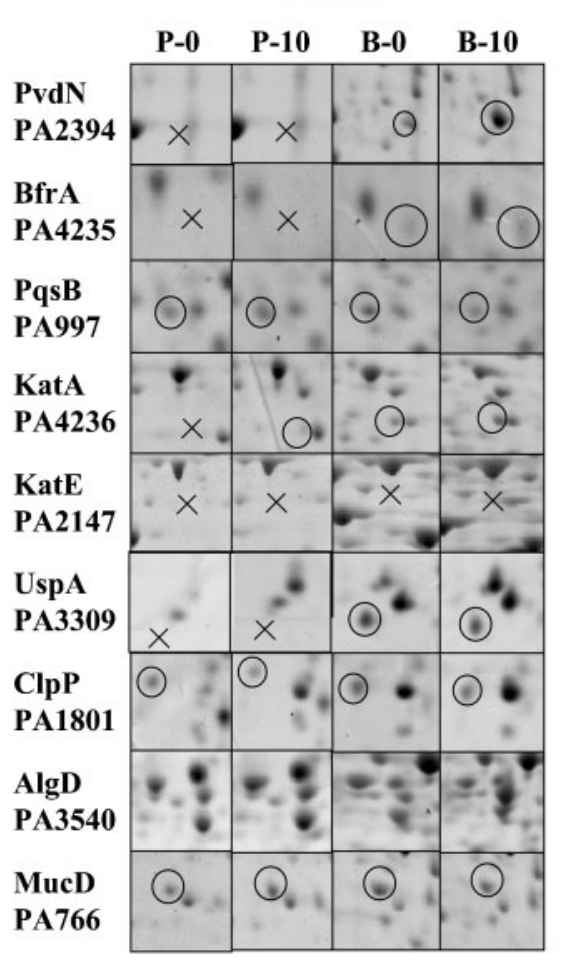

FRD1

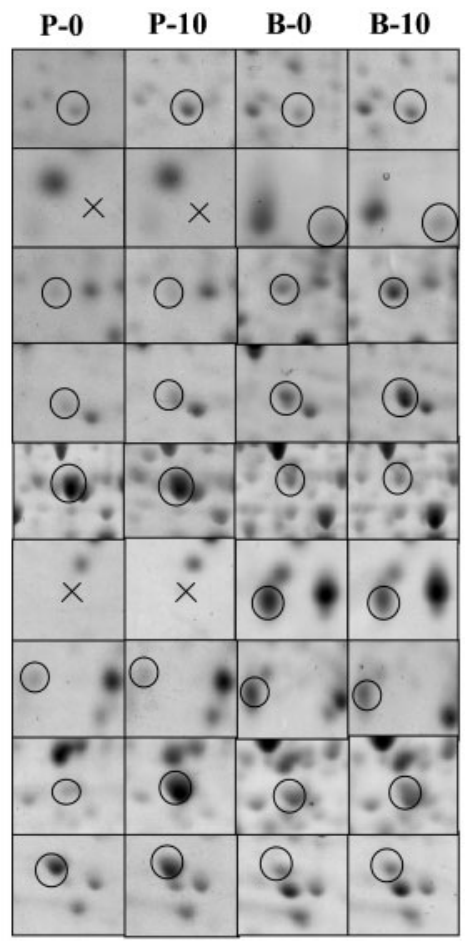

Fig. 4. Sections of $2 \mathrm{D}$ gels showing selected proteins in PAO1 and FRD1 proteomes. The spots from each of the four conditions tested are shown, with circles showing identified spots, and crosses showing the corresponding protein counterpart not detected under the particular condition. $\mathrm{P}-\mathrm{0}, \mathrm{P}-10, \mathrm{~B}-0$ and $\mathrm{B}-10$ are as defined in Fig. 1.
1996) and in some cases controlled by quorum-sensing regulatory circuitry (Hassett et al., 1999). Biofilm cells express higher resistance to bactericidal reactive oxygen intermediates (Elkins et al., 1999). We detected five antioxidant proteins with significantly differing abundances under the effects of $\mathrm{Ca}^{2+}$ and biofilm growth. The major catalase, KatA, was induced in biofilms in both strains (Fig. 4). This protein was also induced by $\mathrm{Ca}^{2+}$ in both planktonic cultures. Expression of katA is positively regulated by RhlR and LasR quorum sensing (Hassett et al., 1999) and also influenced by quinolone signalling (Bredenbruch et al., 2006). Results presented here show a direct relationship between quorum sensing, biofilm growth and amount of KatA. In FRD1, a second catalase, KatE (PA2147), showed the opposite expression profile to KatA, with sixfold higher abundance in the proteomes of planktonic cells than in the biofilms (Fig. 4). KatE was not observed in PAO1 under any of the conditions tested here.

Another oxidative-stress-responsive protein, AhpC, alkyl hydroperoxide reductase, had a very different abundance profile in the two strains. In PAO1 it was induced by $\mathrm{Ca}^{2+}$ in both planktonic and biofilm cells, but was little influenced by biofilm growth (cluster 7). In FRD1 it had decreased abundance in biofilm cells, and was not affected by $\mathrm{Ca}^{2+}$ (cluster 4). Although part of the PQS regulon (Bredenbruch et al., 2006), AhpC does not correlate with the abundance profile of $\mathrm{PqsB}$. In a previous comparison of mucoid and non-mucoid $P$. aeruginosa CF lung isolates, AhpC was detected only in the non-mucoid proteome (Hanna et al., 2000). These discrepancies demonstrate strain variations in oxidative stress responses of $P$. aeruginosa, and indicate complexity in the regulation of this response.

Other proteins possibly involved in oxidative stress are PA3529 and PA3450, which showed greater abundances in PAO1 biofilms, but at high and low $\mathrm{Ca}^{2+}$, respectively. These proteins were not observed in the FRD1 biofilms, demonstrating that both strains responded to oxidative stress, but by the expression of different stress-responsive proteins.

\section{Biofilm growth affects the abundance of chaperones and proteins involved in post- translational modification}

Six proteins (DnaK, GroEL, GrpE, TypA and two homologues of UspA) associated with cellular stress responses, including chaperones and proteins involved in post-translational folding and stabilization, showed increased abundance in biofilm-grown cells of FRD1 (cluster 1; Fig. 4). In PAO1 six stress-response proteins (TypA, both UspA homologues, DnaK, HtpG and Tig) were also induced during biofilm growth. Three of these proteins (DnaK, HtpG and Tig) were induced in biofilms but only with elevated $\mathrm{Ca}^{2+}$ (cluster 3 ). The similarity in profiles of the chaperone/post-translational modification proteins is striking, with six out of eight proteins detected in FRD1 induced in biofilm cells, and six of eight also induced in biofilms of PAO1, but with greater dependence on $\left[\mathrm{Ca}^{2+}\right]$. 
Cellular stress-responsive proteins have been shown to be important in biofilm development. HtpG was previously shown to be induced in mature $P$. aeruginosa $\mathrm{PAO} 1$ biofilms (Southey-Pillig et al., 2005), and DnaK has been detected in the proteome of a mucoid $P$. aeruginosa strain (Hanna et al., 2000). In mycobacteria, GroEL1 is required for mycolate biosynthesis and for biofilm maturation (Ojha et al., 2005). The results presented here expand on those studies by showing that many of the chaperones and posttranslational modification proteins are induced during biofilm growth of both the mucoid and non-mucoid strains of $P$. aeruginosa.

Disulfide isomerase protein DsbA was induced by both $\mathrm{Ca}^{2+}$ and biofilm in PAO1, whereas in FRD1 it was less abundant, and induced only by calcium in biofilm cells. Previously this protein has been shown to be more abundant in the mucoid mucA22 derivative versus wildtype PAO1 (Malhotra et al., 2000), which agrees with our data for planktonic cells. The expression of $d s b A$ is under $\sigma-22$ control, which is required for the activation of alginate biosynthesis genes. A deletion of $d s b A$ in PAO1 resulted in reduced twitching motility and reduced accumulation of extracellular proteases, including elastase (Malhotra et al., 2000), previously demonstrated to be present in the matrix material of FRD1 biofilms (Sarkisova et al., 2005).

\section{Proteases}

In our previous study we showed that calcium addition resulted in increased abundance of three extracellular proteases (AprA, LasB and PrpL) in FRD1 biofilms and that these proteases are present in the alginate extracellular matrix material (Sarkisova et al., 2005). Here we identified five proteases, both intracellular proteases and precursors of secreted proteases, that were influenced by $\mathrm{Ca}^{2+}$ and/or biofilm growth. Expression of the proteases differed between the two $P$. aeruginosa strains. PrpL is an extracellular protease, that we identified in the previous study. Here, we identified its cytoplasmic precursor as being induced in biofilms in both strains. PrpL was also induced by $\mathrm{Ca}^{2+}$ in planktonic FRD1 cells. Previously PrpL has been shown to be $\mathrm{Ca}^{2+}$-regulated in $P$. aeruginosa PA103 (Marquart et al., 2005). PrpL is regulated by PvdS (Wilderman et al., 2001), which also regulates pyoveridine production.

The ClpP protease was also induced during biofilm growth in both strains (Fig. 4). However, in PAO1, ClpP also had high abundance in planktonic culture when $\mathrm{Ca}^{2+}$ was added, thus placing it in cluster 1 for FRD1 and cluster 11 for PAO1. Two other proteases, Thij and PfpI, and a putative protease, PA4171, had differing abundance profiles in the two strains. In FRD1 all three proteases were highly induced in planktonic culture and not observed in biofilms, independently of $\left[\mathrm{Ca}^{2+}\right]$ (cluster 4). However in PAO1, ThiJ and PfpI were affected by elevated $\left[\mathrm{Ca}^{2+}\right]$, but not by biofilm growth (cluster 7). PA4171 was not detected in PAO1. Taken together, these data show that $P$. aeruginosa proteases are influenced by both biofilm growth and $\left[\mathrm{Ca}^{2+}\right]$. However, strain-specific differences in the abundances of the different proteases occur, demonstrating the significance of strain variations in regulation of their production.

\section{Biofilm-induced synthesis of pyocyanin}

In our previous study, we identified biofilm-induced expression of two pyocyanin biosynthetic proteins (Sarkisova et al., 2005). Here we identified seven pyocyanin biosynthetic proteins (PhzB2 and G2, and PhzB1, F1, S, D1 and G1) as highly expressed in biofilms, with little or no expression in planktonic cultures (cluster 1). The expression patterns for these proteins were similar in both $P$. aeruginosa strains. Pyocyanin mediates tissue damage and necrosis during lung infection (Lau et al., 2004). Pyocyanin production is typically observed in stationary-phase cells, and is controlled by rhl quorum sensing (Brint \& Ohman, 1995). Pyocyanin synthesis may also be enhanced by PQS, although indirectly as a result of iron depletion (Bredenbruch et al., 2006; McKnight et al., 2000).

\section{Calcium but not biofilm growth induces expression of AlgD in FRD1}

We have demonstrated previously that calcium causes increased expression of $\operatorname{alg} D$ and increased alginate production in FRD1 (Sarkisova et al., 2005). The proteomic data presented here further substantiate those results with the identification of AlgD in FRD1, which was induced by calcium but not by biofilm growth (cluster 7) (Fig. 4). Interestingly, the serine protease, $\mathrm{MucD}$, which is a modulator in alginate regulation, showed significant induction in planktonic cultures (cluster 4) of FRD1 with little expression in biofilms. Little change in expression of MucD in PAO1 under the different conditions was observed. AlgD was not detected in PAO1, confirming other reports demonstrating that alginate is not the extracellular matrix material for PAO1 (Wozniak et al., 2003), but that it is the primary biofilm matrix material for FRD1 (Nivens et al., 2001; Sarkisova et al., 2005).

Other proteins potentially involved in polysaccharide biosynthesis identified here were GalU, GlgX and GlgP. GalU was highly induced in planktonic cells in both $P$. aeruginosa strains. $\mathrm{GlgX}$, a probable glycosyl hydrolase (PA2160), whose gene resides in a cluster of seven genes possibly involved in polysaccharide degradation, was only detected in PAO1 biofilm cells, where it was induced by $\mathrm{Ca}^{2+}$. These results are consistent with the PAO1 transcriptional studies of Waite et al. (2006). However, in FRD1 GlgX showed the opposite expression profile and was only detected in planktonic cells, where it was less abundant in the presence of $\mathrm{Ca}^{2+}$. GlgP, a glycogen phosphorylase that catalyses glycogen cleavage by removing glucose units from polysaccharide outer chains (Alonso-Casajus et al., 2006), 
also showed increased abundance in planktonic cultures of FRD1. Deletion of $g l g P$ in Escherichia coli has been shown previously to be correlated with the presence of longer external chains in the polysaccharide accumulated by cells (Alonso-Casajus et al., 2006). GlgP is encoded on a gene cluster adjacent to katE, which shows an identical abundance profile in FRD1 (increased expression in planktonic cells).

\section{Nitrogen metabolism}

NosF, $\mathrm{N}_{2} \mathrm{O}$ reductase (PA3394), involved in nitrous oxide respiration, was induced in biofilms of both strains, and influenced by $\mathrm{Ca}^{2+}$ in PAO1 (cluster 3). A similar profile was detected for urease beta subunit UreB (PA4867). nosF belongs to the six-gene nos operon, required for anaerobic respiration of nitrous oxide (Viebrock \& Zumft, 1988). The recent finding that $\mathrm{O}_{2}$ gradients exist across the mucus of the CF lung indicates that $P$. aeruginosa may switch to an anaerobic type of energy metabolism (Yoon et al., 2002). The concentration of nitrite plus nitrate in exhaled breath condensate of CF patients has been shown to be significantly higher than in healthy controls (Ojoo et al., 2005), and CF lung tissues contain increased amounts of calcium-dependent NO synthase (Belvisi et al., 1995), suggesting a potential role for bacterial denitrification in vivo.

\section{Concluding remarks}

In summary, these data show that both a mucoid and nonmucoid strain of $P$. aeruginosa respond to biofilmassociated growth and elevated $\left[\mathrm{Ca}^{2+}\right]$, through dramatic changes in cell physiology, as illustrated by their proteome responses. The two factors caused a cumulative effect on the proteomes of both strains. Calcium probably acts as a signalling molecule for $P$. aeruginosa, particularly during growth in biofilms. Many of the responses exhibited by the two strains were similar, with both showing changes in proteins required for iron uptake, stress response and biosynthesis of extracellular products and polysaccharides. However, the specific responses at the level of individual proteins often differed between the two strains. Thus, the two model $P$. aeruginosa strains, PAO1 and FRD1, commonly used to study infectious processes show both common and different protein changes in response to biofilm growth and elevated $\left[\mathrm{Ca}^{2+}\right]$, and these changes represent different strategies the bacteria may use to adapt to new environments and possibly to evade host defences.

\section{ACKNOWLEDGEMENTS}

We thank Anthony Haag for providing the MALDI-TOF mass spectrometry analysis, and Kate McInnerney for assistance with GeneSpring analyses. This work was supported by Public Health Service grant AI-46588 (to M.J.F.) from the National Institute of Allergy and Infectious Diseases.

\section{REFERENCES}

Alonso-Casajus, N., Dauvillee, D., Viale, A. M., Munoz, F. J., BarojaFernandez, E., Moran-Zorzano, M. T., Eydallin, G., Ball, S. \& Pozueta-Romero, J. (2006). Glycogen phosphorylase, the product of the $g \lg P$ gene, catalyzes glycogen breakdown by removing glucose units from the nonreducing ends in Escherichia coli. J Bacteriol 188, 5266-5272.

Banin, E., Vasil, M. L. \& Greenberg, E. P. (2005). Iron and Pseudomonas aeruginosa biofilm formation. Proc Natl Acad Sci U S A 102, 11076-11081.

Belvisi, M., Barnes, P. J., Larkin, S., Yacoub, M., Tadjkarimi, S., Williams, T. J. \& Mitchell, J. A. (1995). Nitric oxide synthase activity is elevated in inflammatory lung disease in humans. Eur J Pharmacol 283, 255-258.

Boles, B. R., Thoendel, M. \& Singh, P. K. (2004). Self-generated diversity produces "insurance effects" in biofilm communities. Proc Natl Acad Sci U S A 101, 16630-16635.

Bredenbruch, F., Geffers, R., Nimtz, M., Buer, J. \& Haussler, S. (2006). The Pseudomonas aeruginosa quinolone signal (PQS) has an iron-chelating activity. Environ Microbiol 8, 1318-1329.

Brint, J. M. \& Ohman, D. E. (1995). Synthesis of multiple exoproducts in Pseudomonas aeruginosa is under the control of RhlR-RhlI, another set of regulators in strain PAO1 with homology to the autoinducerresponsive LuxR-LuxI family. J Bacteriol 177, 7155-7163.

Britigan, B. E., Roeder, T. L., Rasmussen, G. T., Shasby, D. M., McCormick, M. L. \& Cox, C. D. (1992). Interaction of the Pseudomonas aeruginosa secretory products pyocyanin and pyochelin generates hydroxyl radical and causes synergistic damage to endothelial cells. Implications for Pseudomonas-associated tissue injury. J Clin Invest 90, 2187-2196.

Britigan, B. E., Rasmussen, G. T. \& Cox, C. D. (1994). Pseudomonas siderophore pyochelin enhances neutrophil-mediated endothelial cell injury. Am J Physiol 266, L192-L198.

Costerton, J. W., Lewandowski, Z., Caldwell, D. E., Korber, D. R. \& Lappin-Scott, H. M. (1995). Microbial biofilms. Annu Rev Microbiol 49, 711-745.

Costerton, J. W., Stewart, P. S. \& Greenberg, E. P. (1999). Bacterial biofilms: a common cause of persistent infections. Science 284, 1318-1322.

Davies, D. G., Parsek, M. R., Pearson, J. P., Iglewski, B. H., Costerton, J. W. \& Greenberg, E. P. (1998). The involvement of cell-to-cell signals in the development of a bacterial biofilm. Science 280, 295-298.

Denning, G. M., Railsback, M. A., Rasmussen, G. T., Cox, C. D. \& Britigan, B. E. (1998). Pseudomonas pyocyanine alters calcium signaling in human airway epithelial cells. Am J Physiol 274, L893-L900.

Egan, M. E., Glockner-Pagel, J., Ambrose, C., Cahill, P. A., Pappoe, L., Balamuth, N., Cho, E., Canny, S., Wagner, C. A. \& other authors (2002). Calcium-pump inhibitors induce functional surface expression of $\Delta$ F508-CFTR protein in cystic fibrosis epithelial cells. Nat Med $\mathbf{8}$, $485-492$.

Elkins, J. G., Hassett, D. J., Stewart, P. S., Schweizer, H. P. \& McDermott, T. R. (1999). Protective role of catalase in Pseudomonas aeruginosa biofilm resistance to hydrogen peroxide. Appl Environ Microbiol 65, 4594-4600.

Firoved, A. M. \& Deretic, V. (2003). Microarray analysis of global gene expression in mucoid Pseudomonas aeruginosa. J Bacteriol 185, 1071-1081.

Friedman, L. \& Kolter, R. (2004). Two genetic loci produce distinct carbohydrate-rich structural components of the Pseudomonas aeruginosa biofilm matrix. J Bacteriol 186, 4457-4465. 
Halmerbauer, G., Arri, S., Schierl, M., Strauch, E. \& Koller, D. Y. (2000). The relationship of eosinophil granule proteins to ions in the sputum of patients with cystic fibrosis. Clin Exp Allergy 30, 1771-1776.

Hanna, S. L., Sherman, N. E., Kinter, M. T. \& Goldberg, J. B. (2000). Comparison of proteins expressed by Pseudomonas aeruginosa strains representing initial and chronic isolates from a cystic fibrosis patient: an analysis by 2-D gel electrophoresis and capillary column liquid chromatography-tandem mass spectrometry. Microbiology 146, 2495-2508.

Hassett, D. J., Schweizer, H. P. \& Ohman, D. E. (1995). Pseudomonas aeruginosa sodA and sodB mutants defective in manganese- and ironcofactored superoxide dismutase activity demonstrate the importance of the iron-cofactored form in aerobic metabolism. J Bacteriol 177, 6330-6337.

Hassett, D. J., Sokol, P. A., Howell, M. L., Ma, J. F., Schweizer, H. T., Ochsner, U. \& Vasil, M. L. (1996). Ferric uptake regulator (Fur) mutants of Pseudomonas aeruginosa demonstrate defective siderophore-mediated iron uptake, altered aerobic growth, and decreased superoxide dismutase and catalase activities. J Bacteriol 178, 3996-4003.

Hassett, D. J., Ma, J. F., Elkins, J. G., McDermott, T. R., Ochsner, U. A., West, S. E., Huang, C. T., Fredericks, J., Burnett, S. \& other authors (1999). Quorum sensing in Pseudomonas aeruginosa controls expression of catalase and superoxide dismutase genes and mediates biofilm susceptibility to hydrogen peroxide. Mol Microbiol 34, 1082-1093.

Hentzer, M., Teitzel, G. M., Balzer, G. J., Heydorn, A., Molin, S., Givskov, M. \& Parsek, M. R. (2001). Alginate overproduction affects Pseudomonas aeruginosa biofilm structure and function. J Bacteriol 183, 5395-5401.

Jackson, K. D., Starkey, M., Kremer, S., Parsek, M. R. \& Wozniak, D. J. (2004). Identification of $p s l$, a locus encoding a potential exopolysaccharide that is essential for Pseudomonas aeruginosa PAO1 biofilm formation. J Bacteriol 186, 4466-4475.

Jensen, P. O., Bjarnsholt, T., Phipps, R., Rasmussen, T. B., Calum, H., Christoffersen, L., Moser, C., Williams, P., Pressler, T. \& other authors (2007). Rapid necrotic killing of polymorphonuclear leukocytes is caused by quorum-sensing-controlled production of rhamnolipid by Pseudomonas aeruginosa. Microbiology 153, 1329-1338.

Jesaitis, A. J., Franklin, M. J., Berglund, D., Sasaki, M., Lord, C. I., Bleazard, J. B., Duffy, J. E., Beyenal, H. \& Lewandowski, Z. (2003). Compromised host defense on Pseudomonas aeruginosa biofilms: characterization of neutrophil and biofilm interactions. J Immunol 171, 4329-4339.

Keren, I., Shah, D., Spoering, A., Kaldalu, N. \& Lewis, K. (2004). Specialized persister cells and the mechanism of multidrug tolerance in Escherichia coli. J Bacteriol 186, 8172-8180.

Lau, G. W., Ran, H., Kong, F., Hassett, D. J. \& Mavrodi, D. (2004). Pseudomonas aeruginosa pyocyanin is critical for lung infection in mice. Infect Immun 72, 4275-4278.

Lewis, K. (2007). Persister cells, dormancy and infectious disease. Nat Rev Microbiol 5, 48-56.

Liu, L., Ridefelt, P., Hakansson, L. \& Venge, P. (1999). Regulation of human eosinophil migration across lung epithelial monolayers by distinct calcium signaling mechanisms in the two cell types. J Immunol 163, 5649-5655.

Lorin, M. I., Gaerlan, P. F., Mandel, I. D. \& Denning, C. R. (1976). Composition of nasal secretion in patients with cystic fibrosis. $J$ Lab Clin Med 88, 114-117.

Lyczak, J. B., Cannon, C. L. \& Pier, G. B. (2000). Establishment of Pseudomonas aeruginosa infection: lessons from a versatile opportunist. Microbes Infect 2, 1051-1060.

Lyczak, J. B., Cannon, C. L. \& Pier, G. B. (2002). Lung infections associated with cystic fibrosis. Clin Microbiol Rev 15, 194-222.
Mah, T. F., Pitts, B., Pellock, B., Walker, G. C., Stewart, P. S. \& O'Toole, G. A. (2003). A genetic basis for Pseudomonas aeruginosa biofilm antibiotic resistance. Nature 426, 306-310.

Mai, G. T., Seow, W. K., Pier, G. B., McCormack, J. G. \& Thong, Y. H. (1993). Suppression of lymphocyte and neutrophil functions by Pseudomonas aeruginosa mucoid exopolysaccharide (alginate): reversal by physicochemical, alginase, and specific monoclonal antibody treatments. Infect Immun 61, 559-564.

Malhotra, S., Silo-Suh, L. A., Mathee, K. \& Ohman, D. E. (2000). Proteome analysis of the effect of mucoid conversion on global protein expression in Pseudomonas aeruginosa strain PAO1 shows induction of the disulfide bond isomerase, dsbA. J Bacteriol 182, 6999-7006.

Marquart, M. E., Dajcs, J. J., Caballero, A. R., Thibodeaux, B. A. \& O'Callaghan, R. J. (2005). Calcium and magnesium enhance the production of Pseudomonas aeruginosa protease IV, a corneal virulence factor. Med Microbiol Immunol 194, 39-45.

McKnight, S. L., Iglewski, B. H. \& Pesci, E. C. (2000). The Pseudomonas quinolone signal regulates rhl quorum sensing in Pseudomonas aeruginosa. J Bacteriol 182, 2702-2708.

Musk, D. J., Banko, D. A. \& Hergenrother, P. J. (2005). Iron salts perturb biofilm formation and disrupt existing biofilms of Pseudomonas aeruginosa. Chem Biol 12, 789-796.

Nivens, D. E., Ohman, D. E., Williams, J. \& Franklin, M. J. (2001). Role of alginate and its $\mathrm{O}$ acetylation in formation of Pseudomonas aeruginosa microcolonies and biofilms. J Bacteriol 183, 1047-1057.

Ochsner, U. A. \& Vasil, M. L. (1996). Gene repression by the ferric uptake regulator in Pseudomonas aeruginosa: cycle selection of ironregulated genes. Proc Natl Acad Sci U S A 93, 4409-4414.

Ochsner, U. A., Vasil, A. I. \& Vasil, M. L. (1995). Role of the ferric uptake regulator of Pseudomonas aeruginosa in the regulation of siderophores and exotoxin A expression: purification and activity on iron-regulated promoters. J Bacteriol 177, 7194-7201.

Ohman, D. E. \& Chakrabarty, A. M. (1981). Genetic mapping of chromosomal determinants for the production of the exopolysaccharide alginate in a Pseudomonas aeruginosa cystic fibrosis isolate. Infect Immun 33, 142-148.

Ojha, A., Anand, M., Bhatt, A., Kremer, L., Jacobs, W. R., Jr \& Hatfull, G. F. (2005). GroEL1: a dedicated chaperone involved in mycolic acid biosynthesis during biofilm formation in mycobacteria. Cell 123, 861-873.

Ojoo, J. C., Mulrennan, S. A., Kastelik, J. A., Morice, A. H. \& Redington, A. E. (2005). Exhaled breath condensate $\mathrm{pH}$ and exhaled nitric oxide in allergic asthma and in cystic fibrosis. Thorax 60, 22-26.

Olson, J. C. \& Ohman, D. E. (1992). Efficient production and processing of elastase and LasA by Pseudomonas aeruginosa require zinc and calcium ions. J Bacteriol 174, 4140-4147.

Pier, G. B., Coleman, F., Grout, M., Franklin, M. \& Ohman, D. E. (2001). Role of alginate $O$ acetylation in resistance of mucoid Pseudomonas aeruginosa to opsonic phagocytosis. Infect Immun 69, 1895-1901.

Rani, S. A., Pitts, B. \& Stewart, P. S. (2005). Rapid diffusion of fluorescent tracers into Staphylococcus epidermidis biofilms visualized by time lapse microscopy. Antimicrob Agents Chemother 49, 728-732.

Redly, G. A. \& Poole, K. (2003). Pyoverdine-mediated regulation of FpvA synthesis in Pseudomonas aeruginosa: involvement of a probable extracytoplasmic-function sigma factor, FpvI. J Bacteriol 185, 1261-1265.

Roberts, M. E. \& Stewart, P. S. (2004). Modeling antibiotic tolerance in biofilms by accounting for nutrient limitation. Antimicrob Agents Chemother 48, 48-52. 
Sarkisova, S., Patrauchan, M. A., Berglund, D., Nivens, D. E. \& Franklin, M. J. (2005). Calcium-induced virulence factors associated with the extracellular matrix of mucoid Pseudomonas aeruginosa biofilms. J Bacteriol 187, 4327-4337.

Sauer, K., Camper, A. K., Ehrlich, G. D., Costerton, J. W. \& Davies, D. G. (2002). Pseudomonas aeruginosa displays multiple phenotypes during development as a biofilm. J Bacteriol 184, 1140-1154.

Schuster, M., Lostroh, C. P., Ogi, T. \& Greenberg, E. P. (2003). Identification, timing, and signal specificity of Pseudomonas aeruginosa quorum-controlled genes: a transcriptome analysis. J Bacteriol 185, 2066-2079.

Southey-Pillig, C. J., Davies, D. G. \& Sauer, K. (2005). Characterization of temporal protein production in Pseudomonas aeruginosa biofilms. J Bacteriol 187, 8114-8126.

Stewart, P. S. \& Costerton, J. W. (2001). Antibiotic resistance of bacteria in biofilms. Lancet 358, 135-138.

Stover, C. K., Pham, X. Q., Erwin, A. L., Mizoguchi, S. D., Warrener, P., Hickey, M. J., Brinkman, F. S., Hufnagle, W. O., Kowalik, D. J. \& other authors (2000). Complete genome sequence of Pseudomonas aeruginosa PA01, an opportunistic pathogen. Nature 406, 959-964.

Vasil, M. L., Ochsner, U. A., Johnson, Z., Colmer, J. A. \& Hamood, A. N. (1998). The fur-regulated gene encoding the alternative sigma factor PvdS is required for iron-dependent expression of the LysR-type regulator ptxR in Pseudomonas aeruginosa. J Bacteriol 180, 6784-6788.

Viebrock, A. \& Zumft, W. G. (1988). Molecular cloning, heterologous expression, and primary structure of the structural gene for the copper enzyme nitrous oxide reductase from denitrifying Pseudomonas stutzeri. J Bacteriol 170, 4658-4668.

von Ruecker, A. A., Bertele, R. \& Harms, H. K. (1984). Calcium metabolism and cystic fibrosis: mitochondrial abnormalities suggest a modification of the mitochondrial membrane. Pediatr Res 18, 594-599.

Wagner, V. E., Bushnell, D., Passador, L., Brooks, A. I. \& Iglewski, B. H. (2003). Microarray analysis of Pseudomonas aeruginosa quorumsensing regulons: effects of growth phase and environment. J Bacteriol 185, 2080-2095.
Waite, R. D., Papakonstantinopoulou, A., Littler, E. \& Curtis, M. A. (2005). Transcriptome analysis of Pseudomonas aeruginosa growth: comparison of gene expression in planktonic cultures and developing and mature biofilms. J Bacteriol 187, 6571-6576.

Waite, R. D., Paccanaro, A., Papakonstantinopoulou, A., Hurst, J. M., Saqi, M., Littler, E. \& Curtis, M. A. (2006). Clustering of Pseudomonas aeruginosa transcriptomes from planktonic cultures, developing and mature biofilms reveals distinct expression profiles. BMC Genomics 7, 162.

Walters, M. C., III, Roe, F., Bugnicourt, A., Franklin, M. J. \& Stewart, P. S. (2003). Contributions of antibiotic penetration, oxygen limitation, and low metabolic activity to tolerance of Pseudomonas aeruginosa biofilms to ciprofloxacin and tobramycin. Antimicrob Agents Chemother 47, 317-323.

Whiteley, M., Bangera, M. G., Bumgarner, R. E., Parsek, M. R., Teitzel, G. M., Lory, S. \& Greenberg, E. P. (2001). Gene expression in Pseudomonas aeruginosa biofilms. Nature 413, 860-864.

Wilderman, P. J., Vasil, A. I., Johnson, Z., Wilson, M. J., Cunliffe, H. E., Lamont, I. L. \& Vasil, M. L. (2001). Characterization of an endoprotease $(\mathrm{PrpL})$ encoded by a PvdS-regulated gene in Pseudomonas aeruginosa. Infect Immun 69, 5385-5394.

Wozniak, D. J., Wyckoff, T. J., Starkey, M., Keyser, R., Azadi, P., O'Toole, G. A. \& Parsek, M. R. (2003). Alginate is not a significant component of the extracellular polysaccharide matrix of PA14 and PAO1 Pseudomonas aeruginosa biofilms. Proc Natl Acad Sci U S A 100, 7907-7912.

Yahr, T. L., Mende-Mueller, L. M., Friese, M. B. \& Frank, D. W. (1997). Identification of type III secreted products of the Pseudomonas aeruginosa exoenzyme S regulon. J Bacteriol 179, 7165-7168.

Yoon, S. S., Hennigan, R. F., Hilliard, G. M., Ochsner, U. A., Parvatiyar, K., Kamani, M. C., Allen, H. L., DeKievit, T. R., Gardner, P. R. \& other authors (2002). Pseudomonas aeruginosa anaerobic respiration in biofilms: relationships to cystic fibrosis pathogenesis. Dev Cell 3, 593-603.

Edited by: C. Picioreanu 